DE DE GRUYTER OPEN
Journal of Intercultural Management

Vol. 6, No. 3, September 2014, pp. 91-100 DOI 10.2478/joim-2014-0021

Joanna M. Moczydłowska*

Uczelnia Łazarskiego

Urszula Widelska*

Politechnika Białostocka

\title{
Cultural determinants of employee relationship management
}

\begin{abstract}
: culture context of employee relationship management is the subject of the analysis undertaken in this article. The authors based on the assumption that the knowledge of what values and standards culturally conditioned guides nationalities or ethnic groups constitutes the foundation of people management in transnational organizations. The article contains results of a critical analysis of the concept of Employee Relationship Management (ERM) and its culture context. The research problem undertaken in the article is: how does the cultural and national context influence the process of employee relationship management. On the basis of carried out analyses, it has been concluded that it is possible to distinguish dimensions of culture which support relations building in the workplace. Relationship management with employees is supported by: small power distance, femininity, collectivism and high contextuality.
\end{abstract}

Key words: cultural differences, employee relationship management, typologies of cultures

\section{Introduction}

The aim of the article is to get to know cultural determinants of employee relationship management. Basing on the concept of Employee Relationship Management by W. Stotz [2007], the authors advance a thesis that the way of building relationships between the employee and the organisation, their duration and effects for functioning of the professional employee are in a large extent culturally conditioned. This thesis has been formulated on the basis on of the results of an earlier

\footnotetext{
*joanna@moczydlowska.pl; widelskau@wp.pl
} 
questionnaire survey [Moczydłowska J.M., 2014] on the barriers of employee relationship management. Cultural differences, including the religious and linguistic ones, have been identified as the most important sources of difficulties of employee relationship management by $30 \%$ of respondents taking part in the research. This result justifies the necessity for a deepened analysis of cultural determinants of employee relationship management.

\section{Employee Relationship Management - the epistemological analysis}

The definition of Employee Relationship Management in Polish literature [Lipka A., Winnicka - Wejs A., Acedański J., 2012, p. 132] is interchangeably used with the concept of internal management of relational capital. In a natural way, therefore, it is necessary to point to the genesis of this concept in the theory of relational capital. Relational capital arises as an outcome of interdependence and interaction of related through relationships entities. Studies on the nature and importance of relational capital have been developing for at least 30 years in a broad stream of studies on intangible capital of an organisation (it is alternatively referred to as invisible capital and from the 1990s as intellectual capital) [Edvinsson L., Malone M.S., 1997]1. It is possible to venture an opinion that distinction of relational capital was closely connected with the concept of Customer Relationship Management (CRM) requiring enterprises to focus their attention on customers and put the customer in the centre of all activities of the enterprise and build long-lasting relationships with customers. These relationships were (and still are) perceived in terms of an important source of competitive advantage. While the management of external relational capital can be regarded as the domain of marketing management, the internal relational capital results mainly from the way of implementation of the personnel function. If the aim of CRM is to build loyalty of external customers, based on its widely understood satisfaction, the aim of personnel activities, especially based on the concept of ERM, is to build loyalty of internal customers also based on the satisfaction. This way of thinking is reflected in the concept of marketing personnel (also referred to as marketing staff), that treats an employee as an internal client of the organisation.

The essence of Employee Relationship Management lies in making decisions and undertaking personnel actions aimed at building long-lasting relationships with employees by enabling them to meet their needs, expectations and delivering them increasing benefits of an economic and psychological character. Defined, in this way, Employee Relationship Management is regarded as the base for retention employee management [Lipka A., 2011, p. 205]. In organisations, based on knowledge, the outflow of employees with key, rare and difficult to imitate competen-

1 The term "intellectual capital" was first used in 1969; the first work on the subject appeared in 1975 by G.R. Fiewel, but in the current context, it returned in the scientific literature of management science at the beginning of the 1990s. 
cies constitutes a serious threat. Actions undertaken within the frames of ERM may minimise this problem. Linking employees with the organisation by building an attitude of loyalty, emotional attachment and sense of belonging increases the resistance of employees to offers of competitive companies in the labour market, which makes the enterprise personally, and indirectly, economically more stable, for example, by reducing costs of replacing employees. It should be noted that the aim is to build the real loyalty, not the common or forced one.

The aim of ERM is also to build the brand of the organisation as an attractive employer, it means, attracting from the labour market candidates with the highest level of competencies and the greatest developmental potential. The result of the use of ERM should be the increased employee engagement in the implementation of professional tasks. The base of engagement is, in this approach, the loyalty of employees to the employer. The effect of professionally implemented personnel strategy, based on ERM, is the increase of value of human capital, and thus, the increase of value of the entire organisation. At this point, however, it is necessary to emphasise that ERM has not only economical dimension, but also the humanising one [more on the subject: Jamka B., 2011]. In other words, it does not only provides a measurable benefit for the employer, resulting from the value generated by the high-quality human capital, but also means investing in employees, that is, providing the specific balance of benefits for the employer and employee. In a different way, we can say that Employee Relationship Management means striving to integrate the aims of the organisation and its employees, and even co-responsibility for the organisation.

What distinguishes the concept of Employee Relationship Management from other concepts, such as Talent Management or Professional Competency Management, is drawing attention to the emotional context of the relationship of employer and employee. High efficiency of work is supposed to be achieved by building relationships based on emotional attachment and engagement of an employee. Therefore, it is not merely the behavioural dimension consisting in "being" in the organisation, but primarily, the emotional dimension manifesting itself in the form of a specific sympathy, that is, a positive attitude towards the employer. Emotional relationships between employees and the organisation can result from a variety of premises of an emotional and symbolic character. They include: compliance of the personal system of values with the system of values present in the organisational culture, the sense of breaking social norms in case of departure from the company, desire to continue and even strengthen the relationship of trust, sense of agency and professional efficiency [Lipka A., 2011, p. 90; Moczydłowska J.M., 2013a, pp. 29-39].

The state of positive emotional bonds between employees and the organisation is possible to achieve by far-reaching individual incentive influences. Just as external customers look for tailored offers, similarly, internal customers have different needs 
and expectations towards personal products and services [Stotz W., 2007, p. 32]. A responsible employer is aware that not only money is the incentive in choosing the place of work and the quality of the work. Equally important are: opportunity for professional development, clear objectives or attractive, interesting professional tasks, as well as friendly organisational culture based on trust and good interpersonal relationships within employee teams [Moczydłowska J.M. 2013b pp. 32-39].

\section{Culture models and management}

The ongoing process of internationalisation of business activities imposes on the managerial staff a duty to take into account the cultural context of management. In a particular way, this regards people management who are specific "carriers' of various patterns and cultural norms strongly conditioned by, among others, the national identity of employees, their language, religion, and rooted in the centuriesold tradition of customs. The working environment of most enterprises is currently a place of mutual interaction between people from different cultures. This state of affairs leads to the occurrence in organisations many different: systems of value, work styles and work attitudes, ways of perceiving reality, preferences and beliefs. As a result, more and more frequently and on an increasing scale, managers are forced to operate in a multicultural environment and use more and more culturally diverse workforce. It should be emphasised, that cultural diversity is a current and important issue in spite of increasing globalization whose indirect consequence is interpenetration of cultures and increasing unification of behavioural patterns and cultural norms.

As aptly described by one of the pioneers of the research on cultural patterns, G. Hofstede [1993], national culture is responsible for the specific "programming of the mind" that affects the way of people's thinking, feeling and acting. Researchers of cultural determinants of management practices [cf. Rozkwitalska M., 2008, pp. 80-87] attempt to identify the influence of cultural environment on motivating employees, leadership, degree of decentralisation of power, organisation of activities, solving conflict situations, group management, negotiation, etc.. In all these areas, multiculturalism constitutes an important issue; hence the efforts aiming at identifying the basis of cultural differences and creating models that reflect behavioural patterns and cultural norms. These models are supposed to facilitate the management by providing knowledge of cultural differences in the perception of the world. An example of such a model is Fukuyama's model of trust [1995]. It is a one-dimensional model as it divides cultures according to one criterion: the level of trust. Countries belonging to the cultures of low trust (e.g. countries of southern Europe, such as Italy or Spain) are characterised by close family and clan ties and a low level of trust in business relationships. The management is dominated by bureaucratic rules and procedures and reluctance to enter into relationships with 
own employees. Great significance is assigned to the hierarchy which performs the role of a regulator complementing the ethical principles. Countries with a high level of trust are dominated by strongly developed social, friendly ties, which mean that people are inclined to build relationships also beyond the family. Little emphasis is put on formal regulators of behavioural patterns. A positive climate of cooperation defined by a high level of trust leads to reduction of labour costs and increase of innovation through group work and delegation of authority [Fukuyama F., 1995, pp. 27 - 28].

Table 1. Multidimensional models of culture

\begin{tabular}{|c|c|}
\hline \multicolumn{2}{|l|}{ G. Hofstede's model } \\
\hline $\begin{array}{l}\text { Attitude towards the importance of group and } \\
\text { individual interests }\end{array}$ & collectivism versus individualism \\
\hline $\begin{array}{l}\text { Attitude towards the hierarchy and its rel- } \\
\text { evance }\end{array}$ & power distance \\
\hline Attitude towards incentive stimuli & masculinity versus femininity \\
\hline $\begin{array}{l}\text { Attitude towards unpredictable events and } \\
\text { changes }\end{array}$ & $\begin{array}{l}\text { acceptance of uncertainty versus rejection of } \\
\text { uncertainty }\end{array}$ \\
\hline $\begin{array}{l}\text { Attitude towards time, time perspective ac- } \\
\text { cepted at work and in life }\end{array}$ & $\begin{array}{l}\text { long-term orientation versus short-term orienta- } \\
\text { tion }\end{array}$ \\
\hline \multicolumn{2}{|l|}{ R.R. Gesteland's model } \\
\hline $\begin{array}{l}\text { Attitude towards a partner and the way of } \\
\text { conducting business }\end{array}$ & pro-partnership versus pro- transactionalism \\
\hline $\begin{array}{l}\text { Attitude towards conventions, hierarchy, prin- } \\
\text { ciples, rules and ways of showing respect }\end{array}$ & formality versus informality \\
\hline Attitude towards time & monochronicity versus polychronicity \\
\hline Methods of communication & restraint versus expressiveness \\
\hline \multicolumn{2}{|c|}{ Seven dimensions of culture in F. Trompenaars and C. Hampden-Turner's model } \\
\hline Attitude towards people & $\begin{array}{l}\text { universalism versus particularism } \\
\text { individualism versus collectivism } \\
\text { restraint versus emotionality } \\
\text { fragmentation versus wholeness } \\
\text { achieved status versus ascribed status }\end{array}$ \\
\hline Attitude towards time & sequentialism versus synchronism \\
\hline Attitude towards the environment & harmony versus aggressiveness \\
\hline
\end{tabular}

Source: own study based on: Hofstede G. and Hofstede G.J.,2007; Gesteland R.R., 2002; Trompenaars F. and Hampden-Turner Ch., 2002. 
The most known multi-dimensional culture models are models of G. Hofstede, R. R. Gesteland and F. Trompenaars and C. Hampden-Turner (cf. Table 1). Each of them describes culture in many dimensions indicating their influence on human behaviours, his/her perception of environment and time and individual system of values. Considering the subject of the article, in the further part of the text these dimensions will be analysed in detail that are most relevant for employee relationship management.

\section{Cultural determinants of emotional reactions in the workplace}

The concept of ERM is based on the belief in the exceptional value of a positive emotional connection of employees and the organisation. In the context of the subject of the article, it is justified, therefore, to ask how cultural differences may influence the willingness of employees to emotional engagement in relationships with the employer. It is a more precise question about cultural differences in experiencing and expressing by people own emotions. The authors do not feel competent to enter the anthropological and psychological discourse over the nature of emotions and decide whether emotions are universal internal states of biological bases, or rather relative, cultural constructs. After numerous leading figures [cf. Ekman P. and Davidson R., 1994; Reiter M. and Starczuk J., 2012], we assume that people's emotions, the way of their experiencing and expressing, are conditioned by many variables, especially by personality, gender, age and membership to a particular social, national or ethnic group. There are no reasons to presume that any other variables are responsible for emotional reactions arising in the workplace and in the relation of the performed work (the profession, organisational role). Thus, it is reasonable to strive to identify cultural patterns, which - besides before mentioned variables - shape the specificity of an emotional connection of employees and the organisation.

Among cultural dimensions relating directly to human emotionality is restraint versus expressiveness of R. R. Gesteland's model [2002], which corresponds to restraint versus emotionality of F. Trompenaars and C. Hampden-Turner's model [2002]. The authors describing cultural differences in expressing emotions, at opposite poles put cultures in which spontaneous and open expression of emotions are taken as natural and those in which restraint, moderation and reserve are expected. In countries such as Argentina, Italy or Spain, that is those that are treated as examples of expressive cultures, emotions are expressed by loud talking, lively gestures, shortening spatial distance between interlocutors, frequent and intense eye contact and impulsiveness. On the other hand, in countries such as Germany, Austria and Poland, such expression of emotions is not well seen. The degree of social consent for intensive expression of emotions in a variety of situations, including in the workplace, is much smaller. In reserved cultures, people expect a higher degree of rationality in decision making. 


\section{Culture and building relationships in the work environment}

Among cultural dimensions that have the greatest influence on relationships between employees and supervisors is power distance of G. Hofstede's typology. It is defined as "the extent to which less powerful members of organisations and institutions accept and expect unequal power distributions" [Hofstede G. and Hofstede G. J., 2007, p. 58]. Inequality of power is a widespread phenomenon occurring in all cultures, but societies have different approaches to it. In low power distance cultures, people are seen as "naturally" equal and, therefore, inequalities in the access to power evoke objection. It is considered obvious that people exercising power are subjects to continuous monitoring in the area of ethics. The teamwork is promoted, in which people cooperate in order to achieve objectives of the organisation on principles of partnership. In large power distance cultures, inequalities are treated as justified, even desirable, because they ensure law and order. The superior imposes emotional distance in relationships with subordinates treating them as a potential threat to his/her position in the organisation. Power is primal in relation to morality. Countries characterised by a particularly high level of power distance are: Ecuador, Guatemala, Venezuela, Panama, as well as Japan, Belgium and France. In contrast, small power distance is visible in Scandinavian and Anglo-Saxon countries and Germany.

Table 2. Culture dimensions as a favourable and impeding factor to build relationships in the workplace

\begin{tabular}{|l|l|}
\hline $\begin{array}{l}\text { Culture dimension that is favourable to build } \\
\text { and strengthen relationships in the work envi- } \\
\text { ronment }\end{array}$ & $\begin{array}{l}\text { Culture dimension that impedes building and } \\
\text { strengthening relationships in the work envi- } \\
\text { ronment }\end{array}$ \\
\hline Small power distance & $\begin{array}{l}\text { Large power distance } \\
\text { Femininity }\end{array}$ \\
Collectivism & $\begin{array}{l}\text { Individualism } \\
\text { High context }\end{array}$ \\
\hline
\end{tabular}

Source: own study

Building and maintaining employee's relationships with the team and organisation as a whole is much easier in countries dominated by a collectivist culture. Collectivism versus individualism is dimension highlighted in several models of cultures (cf. Table 1). Its authors [cf. Hofstede G. and Hofstede G.J., 2007, Trompenaars F. and Hampden-Turner C., 2002] agree that people representing various cultures differ in terms of giving validity to individual and group interests. Most features of the collectivist culture are visible in countries in which operates Confucianism, i.e. in Asian countries: China, Korea and Japan. These cultures are also referred to as "shame cultures" in opposition to Western cultures that are "guilt cultures." 
This means that norms of conduct determine there a concept of shame consisting in regulating functioning in the society by a strong emphasis on adaptation to the group (maladjustment brings shame, social rejection, lack of unity with the group, including the loss of identity). In a milder form, collectivism is seen in European countries, e.g. Greece or Portugal.

In collectivist culture countries, employees perceive themselves as members of the group and treat its other members in a privileged way expecting loyalty in return. It fosters building strong bonds and, consequently, long-lasting relationships. In contrast, in individualistic groups regulation of social norms is more rooted in an individualistic notion of morality, reward and punishment system, for example, religious concepts of sin, salvation, heaven and hell. In individualistic culture countries (mainly the United States and Anglo-Saxon countries, but also to a large degree, Poland and Germany), interpersonal relationships are not regarded as value in itself, but as a tool for implementation individual, and in extreme cases, even selfish objectives. Employees tend to achieve individual results and want to be rewarded for them. Making the individual remuneration dependent on the team performance raises opposition. Meeting the needs of autonomy and self-realisation in the working environment is more important than satisfying the needs of belonging. The power of relationship and identification with the employer is much smaller.

Another dimension of culture of fundamental importance for building and maintaining employees' relationships with the organisation is masculinity versus femininity. Although it is quite a controversial dimension as it defines the assigned social roles (usually stereotypically) between genders, it has its far-reaching consequences for interpersonal relationships in the workplace. In "female" societies (for example, in the Scandinavian countries, Belgium and the Netherlands), the idea of the common good is very vivid: dominates the cooperative approach, perception of needs of another person and building relationships [more on the subject: Kisil A., Moczydłowska J. M., 2014]. Good atmosphere in the workplace and a sense of community are more important than short-term tangible results achieved through internal competition and rivalry. "Female" societies promote partnership, gender equality and democratic leadership. Harmony and social solidarity, which are distinguishing features of a female culture, constitute for employees the source of meeting one of the basic needs of groups: the safety need. This means, that for organisations operating in such a culture it is much easier to manage employee relationships than for organisations dominated by a male national culture.

Dimension of culture that plays an important role in building relationships in the work environment is context also referred to as wholeness versus fragmentation [Rozkwitalska M., 2008, p. 85]. In comprehensive cultures (high context), professional and personal lives intertwine with each other. Contacts in the workplace are not treated as strictly official. For employees, it is natural to build deeper and more 
personal contacts with colleagues than it happens in low context cultures. This fosters building and maintaining relationships, even though it also carries some risk, e.g. too personal treatment of criticism of ideas or behaviours associated with the performed work. This raises a risk of excessive frustration of employees and entering into conflicts. Moreover, a large depth of bonds may cause a certain tightness of the group, and hence difficulties in adaptation and integration of new members of the organisation. Attributes of a high context culture can be observed, for example, in Far East countries, but also in Southern and Eastern Europe. In contrast, a low context culture dominates in the USA and in Northern and Western Europe.

\section{Conclusion}

It is a current statement that cultural diversity is a human feature and organisational cultures are settled in the cultural heritage of a given country or region. And, although individual and team behaviours are conditioned by many diverse factors, cultural determinants play a particularly important role. This also refers to employee relationship management, that is building and maintaining long-term relationships between an employee and employer - relationships based on positive emotions, loyalty and engagement. This article attempts to indicate which cultural dimensions, highlighted in the most famous models of cultures, are favourable to this process, and which can be a potential source of difficulties for practitioners willing to implement the ERM concept. As interesting, we regard the fact that the birthplace of the ERM concept is Germany, a country characterised by an individualistic, male and low context culture, thus impeding building and strengthening relationships of employees and the organisation. Indirectly, this is a proof that none of the cultures does not exclude the use of this concept for more efficient management, but only makes this process more difficult.

We consider the influence of cultural factors on relationship management with employees as an open subject and worth detailed empirical research. What needs some verification are the hypotheses concerning the role of a language and the style of communication being culturally determined, which are vital relationship determinants within the work environment. Further research should also take into consideration the factor of the age of employees which, being "placed" on cultural variables, can indicate the impact of cultural conditioning within particular age groups. It also seems reasonable to check the influence of religious beliefs of employees on their relationships in the organization. 


\section{Bibliography}

Edvinsson, L. and Malone M.S., (1997) Developing Intellectual Capital at Scandia, Long Range Planning 30.3, pp. 366-373.

Ekman, P. and Davidson, R. (1994) The Nature of Emotion: Fundamental Questions, New York: Oxford University Press.

Fukuyama, F. (1995) Trust: the Social Virtues and the Creation of Prosperity, Free Press.

Gesteland, R.R. (2002) Różnice kulturowe a zachowania w bižnesie, Warszawa: PWN.

Hofstede, G. (1993) Cultural Constrains In Management Theories, Academy of Management Executive, No 7, pp. 81-94.

Hofstede, G. and Hofstede, G.J. (2007) Kultury i organizacje, Warszawa: PWE.

Jamka, B. (2011) Czynnik ludzkei we wspótczesnym przedsiębiorstwie: zasób czy kapitat? Od zarzadzania kompetencjami do zarzadzania różnorodnościa, Warszawa: Wolters Kluwer bussines.

Kisil, A. and Moczydłowska, J.M. (2014) Wrażliwość organizacji jako warunek implementacji koncepcji dobra wspólnego na poziomie zarządzania kapitałem ludzkim, Myśl Ekonomiczna i Polityczna, nr 4 (during the procedure of publishing).

Lipka, A. (2011) Employee Relationship Management (ERM) jako trend rozwoju w obszarze funkcji personalnej, Problemy Zarzqdzania, vol. 9, nr 4 (34), pp. 204-216.

Lipka, A., Winnicka - Wejs, A. and Acedański, J. (2012) Lojalność pracownicza. Od diagnozy typów lojalności pracownikón do zarzqadzania Relacjami z Pracownikami, Warszawa: DIFIN.

Moczydłowska, J.M. (2014), Sources of difficulties in employee relationship management (in the assessment of the managerial staff) - in review.

Moczydłowska, J.M. (2013a) Employees' commitment management in the assessment of managers (based on the results of quality research). in: Borkowski, S. and Stasiak-Betlejewska, R. (ed.) Toyotarity. People, processes, quality improvement, Alba Iulia: Aeternitas Publishing House.

Moczydłowska, J.M. (2013b) Zarzqdzanie relacjami zpracownikami (ZR₹P) - nowe spojrzenie na relacje organizacji z.pracownikami, „Przedsiębiorczość i Zarządzanie”, tom XIV, zeszyt 12, część II, pp. 33-42.

Rajtar, M. and Starczuk, J. (2012) Emocje w kulturze, Warszawa: Wydawnictwo Uniwersytetu Warszawskiego.

Rozkwitalska, M. (2008) Zarządzanie międzynarodowe a modele zarządzania, Organizacja i Kierowanie, vol. 132, nr 2, pp. 78-102.

Stotz, W. (2007) Employee Relationship Management. Der Weg zu engagierten und effizienten Mitarbeitern, Műnchen: Oldenbourg Wissenschaftsverlag.

Trompenaars, F. and Hampden-Turner Ch. (2002) Siedem wymiarón kultury. Znacz̧enie różnic kulturowych w działalności gospodarczej, Kraków: Oficyna Ekonomiczna. 